\title{
PRATIA PLATYCALYXIS A SYNONYM OF P. IRRIGUA (CAMPANULACEAE: LOBELIOIDEAE)
}

\author{
by D.E. Albrecht
}

ALBRECHT, D.E., 1992 (31:x): Pratia platycalyx is a synonym of P. irrigua (Campanulaceae: Lobelioideae). Pap. Proc. R. Soc. Tasm. 126: 123-124. https://doi.org/10.26749/rstpp.126.123 ISSN 0080-4703. National Herbarium of Victoria, Birdwood Ave, South Yarra, Victoria, Australia 3141

Pratia irrigua $(\mathrm{R} . \mathrm{Br})$ Benth., hitherto believed to be a restricted Tasmanian endemic, is shown to be conspecific with the extremely variable $P$. platycalyx (F. Muell.) Benth. The name P. irrigua is retained, as its basionym predates that of $P$. platycalyx. An amended morphological description is presented.

Key Words: Campanulaceae, Pratia, South Australia, Victoria, Tasmania.

Pratia irrigua (R. Br.) Benth. is currently regarded as a vulnerable Tasmanian endemic (Briggs \& Leigh 1988; Kirkpatrick et al. 1991). As recently as the early 1970s, it was known only by the typespecimen collected by RobertBrown from the islands of the Kent Group. Four contemporary collections of $P$. irrigua are housed at the Tasmanian Herbarium, though in some cases they have been referred somewhat hesitantly to that species (A.M. Buchanan, pers. comm.). Two of these specimens, collected by J. Whinray from Deal and Long Islands, are depicted in Curtis \& Stones (1973) and look suspiciously similar to forms of P. platycalyx (F. Muell.) Benth., a species found in Victoria, South Australia and Tasmania. A brief study was undertaken to determine whether $P$. platycalyx and $P$. irrigua are distinct species or whether they are simply forms of one variable taxon.

Published taxonomic treatments of Pratia (e.g. Bentham 1868, Curtis 1963, Wimmer 1943) separate P. irrigua and $P$. platycalyx on the basis of leaf shape and pedicel length; the former have ovate or orbiculate leaves and sessile to subsessile flowers, the latter have linear to obovate leaves and flowers with longer pedicels (at least half as long as the leaves or at least as long as the fruit).

Despite the minimal material and rather poor condition of Brown's type of Pratia irrigua, it has been possible to confirm that the specimens have flowers with short pedicels 1-2 mm long and possess some leaves that are orbiculate. However, the leaves are not uniformly orbiculate, nor are they ovate as previously described, but vary in shape from oblanceolate-spathulate to lanceolate. Although most of the leaves on the type are broad, the few intact expanding distal leaves are considerably narrower, suggesting that leaf shape may well be related to stage of growth. The small leaf size and short internodes also give one the impression that the specimens were collected from a stunted, perhaps juvenile (or resprouting) plant.

Examination of herbarium specimens of $P$. platycalyx ar the National Herbarium of Victoria (including syntypes) and populations in situ has shown it to be an extremely variable species. Most specimens have oblanceolate-elliptic leaves but shape varies from linear to orbiculate. Leaf indumentum and the degree of marginal toothing are similarly variable. As in the type of $P$. irrigua, leaf polymorphism appears to be at least partly related to the stage of growth, as evidenced by the generally broader lower leaves. Environmental conditions also appear to influence leaf size and shape. Plants from more exposed sites subject to higher levels of salinity tend to have shorter \pm broader leaves. When plants from such sites are transferred to containers and irrigated with fresh water, subsequent growth has considerably longer, relatively narrower foliage. Pedicel length is similarly variable, ranging from $0.5-20 \mathrm{~mm}$ long. However, variation in pedicel length does not appear to be so clearly linked to stage of growth or environmental conditions.

From the level of variation observed in $P$. platycalyx, it is clear that the two characters used to distinguish it from $P$. irrigua are not reliable. Leaf shape and pedicel length in $P$. platycalyx can vary enormously within a population or within an individual plant. Furthermore, as leaf shape and pedicel length vary independently, there is no consistent correlation between short, broad leaves and short pedicels, or conversely, between narrower leaves and long pedicels. As the type of $P$. irrigua is encompassed in the level of variation found in $P$. platycalyx, the two are here regarded as conspecific, the earlier published name $P$. irrigua having priority. A description of the more broadly circumscribed $P$. irrigua is here presented.

Pratia irrigua (R. Br.) Benth., Fl. Austr. 4: 132 (1868) Lobelia irrigua R. Br., Prodr. 563 (1810)

Laurentia platycalyx F.Muell., Trans. Vict. Inst. 1: 39 (1855) Lobelia platycalyx (F. Muell.) F.Muell.

Fragm. 4: 183 (1864)

Pratia platycalyx (F.Muell.) Benth., Fl. Austr. 4: 132 (1868)

Dioeciousor gynodioecious perennial herb. Stems procumbent or decumbent, 士zigzagged, glabrous or rarely with scattered, short, spreading hairs, rooting at nodes. Primary roots thick and little-branched. Leaves distichous; blades rather thick, linear, elliptic, lanceolate, oblanceolate, obovate or orbiculate, 2-40 $\mathrm{mm}$ long, $1-8 \mathrm{~mm}$ wide, glabrous and lustrous, or occasionally with short fine hairs, particularly on margins; margins entire, or with $1-5$ short teeth on either side, each tooth with a minute translucent region towards apex; apex obtuse to subacute, base attenuate, sometimes simulating a petiole. Flowers axillary, solitary, borne at irregular intervals along the stem, male, female and hermaphrodite flowers superficially similar. Pedicels $0.5-20 \mathrm{~mm}$ long, glabrous. Hypanthium obconical in male flowers, ellipsoid to ovoid in female and bisexual flowers, sometimes asymmetrical, glabrous. Calyx lobes erect or spreading, triangular, $0.4-1.5 \mathrm{~mm}$ long, glabrous. Corolla subregular, $1.8-4.5 \mathrm{~mm}$ long, glabrous; lobes spreading or recurved, subequal, white on both surfaces or mauve-tinged abaxially, acute; tube very short and split to base along the upper side. Filaments 
attached to the upper edge of the hypanthium, fused just below anther tube, glabrous. Anther tube shorter than the corolla, white and sterile in female flowers, blue-black and 1-1.2 $\mathrm{mm}$ long in male and bisexual flowers, glabrous, the apex of the two lower anthers each with a seta $0.1-0.3 \mathrm{~mm}$ long and a cluster of short hairs c. $0.1 \mathrm{~mm}$ long. Stigma 2-lobed, densely papillose. Fruitellipsoid to broadly ellipsoid, sometimes asymmetrical, slightly compressed, $5-8 \mathrm{~mm}$ long, $3.5-5.5 \mathrm{~mm}$ wide, glabrous, indehiscent. Seeds light brown, ellipsoid, compressed, $0.7-0.9 \mathrm{~mm}$ long, $0.5-0.7 \mathrm{~mm}$ wide, testa minutely pitted.

Distribution

South Australia, Victoria and Tasmania.

\section{Habitat}

Occurring on heavy, seasonally damp soils in saltmarsh, wetlands and damp grassland. Ground water varies from fresh to sub-saline.

\section{REFERENCES}

BENTHAM, G., 1868: FLORA AUSTRALIENSIS: A DESCRIPTION OF THE PLANTS OF THE AUSTRALLAN TERRITORY. Vol. 4, Reeve, London: 132.

BRIgGS, J.D. \& LEIGH, J.H., 1988: RARE OR THREATENED AUSTRALLAN PLANTS. Special Publication 14. Australian National Parks and Wildlife Service, ACT: 56, 221.

CurTIS, W.M., 1963: THE STUDENT'S FLORA OF TASMANIA. Part 2, Government Printer, Tasmania: 412 pp.

Curtis, W.M. \& STONEs, M., 1973: THE ENDEMIC FLORA OF TASMANIA. Part IV, The Ariel Press, London: 278-279.

Kirkpatrick, J.B., Gilfhdder, L., Duncan, F. \& Harris, S., 1991 : Reservarion status and priorities for Tasmanian plants 1. Angiospermae (Dicotyledonae). In Banks, M.R. et al. (eds): ASPECTS OF TASMANIAN BOTANY - A TRIBUTE TO WINIFRED CURTIS. Royal Sociery of Tasmania: $163-$ 172.

Wimmer, F.E., 1943: Campanulaceae-Iobelioideae. Das Pfanzenreich. Heft 106: 105-108.

(accepted 7 February, 1992) 